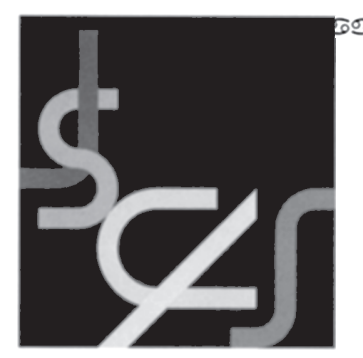

\title{
Newsletter No. 73
}

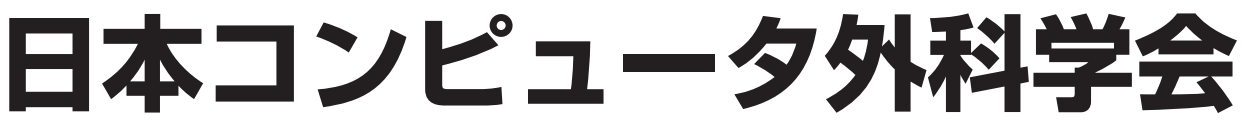

\section{今号の内容}

- 第 27 回日本コンピュータ外科学会大会報告

- 平成 30 年度定時社員総会報告

・CARS 2019 お知らせ/IPCAI2019

・ MICCAI 2019 お知らせ

・関連学会のお知らせ

（期限や内容などは変更されることがありますので詳細は必ず各大会のホームページなどでご確認下さい）

i ) 第 58 回日本生体医工学会大会

ii）第 7 回看護理工学会

iii）生体医工学シンポジウム 2019

iv) 第 13 回日本 CAOS 研究会

v) CAOS International 2019

vi) Photonics West 2019

vii) Medical Imaging 2019

viii) HSMR 2019

ix) ISBI 2019

x) EMBC 2019

xi）第 28 回ライフサポート学会フロンティア講演会

xii) LIFE 2019

\section{・学会ホームページ（www.jscas.org）ご案内}

\section{第 27 回日本コンピュータ外科 学会大会}

第 27 回日本コンピュータ外科学会大会が「ディープ ラーニング, データサイエンス時代のコンピュータ外 科」をテーマとして, 奈良県文化会館にて 11 月 9 日 (金) 〜11日（日）の日程で開催されました。 大会長 は奈良先端科学技術大学院大学の佐藤嘉伸教授が務め られました，今大会では AI に関する特別講演やシン ポジウム, ハンズオンセミナーが開催されました.

初日は特別講演 1「ビッグデータと AIによる次世代 医療基盤」が喜連川優先生（国立情報学研究所所長）
により行われました。シンポジウム $1 「 \mathrm{AI}$ 医療機器開 発の規制と製品化への道」では，技術のみならず，医 療機器の社会実装に必要となる考え方が紹介されまし た。また，ハンズオンセミナー 1 「個別 DICOM 画像 に基づく $\mathrm{VR} / \mathrm{AR} / \mathrm{MR}$ 手術支援一ポリゴン作成から $\mathrm{VR} / \mathrm{AR} / \mathrm{MR}$ アプリ作成, 3D プリンターヘ一」が実施 されました。

2 日目にはシンポジウム $2\lceil\mathrm{ImPACT}$ バイオニック ヒューマノイドが拓く新産業革命一これまでの成果と 今後の展望一」では内閣府 ImPACT プログラム「バイ オニックヒューマノイドが拓く産業革命」のプロジェ クトの進渉状況と今後の展望が紹介され, ミニシンポ

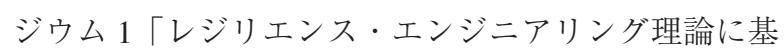


づく手術安全の新展開」では，医療安全のアプローチ として注目されているレジリエンス・エンジニアリン グの理論の概要, 最近の研究成果の紹介がなされまし た。また，ハンズオンセミナー2「外科領域における 医用画像の深層学習」が実施されました。一般社団法 人日本医工ものづくりコモンズ主催の特別シンポジウ ム「医工連携オープンイノベーションによる医療機器 開発」も開催され，医工連携の現況についての報告が 行われました，その他，ランチョンセミナー，日立メ ディコ賞の受賞論文の発表と定時社員総会も開催され ました，夕刻からは懇親会が開催され，学会誌論文賞 (医学賞, 工学賞, 優秀症例賞) の表彰も行われまし た。

3 日目には特別講演 2「泌尿器科領域におけるコン ピュー夕外科」が浮村理先生 (京都府立医科大学教授)

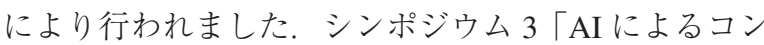
ピュー夕外科の変革」が開催され, AI 技術によるコン ピュータ外科の変革が議論され，ミニシンポジウム 2 「医療ロボティクスの新展開一世界と戦うために一」お よびミニシンポジウム 3 「コンピュータ外科の臨床適

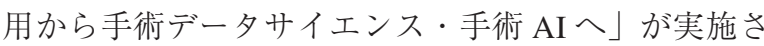
れました。

本年は 3 日間で一般演題は，ロボット・マニピュ レータ, VR・トレーニング・シミュレーション，画 像，手術場・環境システム，ナビゲーション，境界領 域, 内視鏡, 手術機器・デバイス, 共同研究者募集, 安全・評価に関する 11 のセッションが開催され, 総計 114 件の研究発表が行われました。今回の一般演題 セッションでは各演題ショートプレゼンに続き，ポス ターセッションが行われ，個別にじっくり討論が行わ れました。また，共同研究者募集セッションや若手交 流（YIN：Young Investigator Networking）セッションが 設けられ，新たな連携・交流の促進が図られました。

奈良先端科学技術大学院大学のスタッフのご尽力 や，発表，参加して活発な議論をいただいた会員の皆 様のおかげで，有意義な大会となりました。なお，次 年度の第 28 回大会は, 東京大学医学部の小野稔先生を 大会長に，2019年 11 月 22 日（金）～24日（日）の日 程で東京大学本郷キャンパスにて開催される予定です。

\section{平成 30 年度定時社員総会報告}

一般社団法人日本コンピュータ外科学会平成 30 年 度定時社員総会が 11月 10日（土） 13：50 から，奈良 県文化会館 小ホール（大会第 1 会場）にて開催されま した。

運営委員会委員長より平成 29 年度の事業報告, 収支 決算報告が行われました。2017 年度 CAS Young Investigator Award（日立賞）Gold 賞 1 件, Silver 賞 3 件, 2018 年度論文賞は医学賞 1 件, 工学賞 1 件, 優秀症例 賞 1 件の選定を行ったことが報告されました。また会 計監査の結果，適法，正確であったことも報告されま した，平成 30 年度の事業計画，収支予算案の説明があ り，賛成多数にて承認されました。また2019年学会大 会の大会長に小野稔先生 (東京大学医学部), 副大会長 に中郡聡夫先生 (東海大学医学部)が選任されました。

若手育成の充実，財務状況強化のため，年会費の改 定が提案され，1）正会員の会費を年額 12,000 円とす ること，2）理事の会費を年額 15,000 円とすること,

3） 2018 年度から実施すること，4）值上げ分の使途等 に関する会員向けの説明を眓ること，が承認されまし た。ささに，名誉会員 2 名，土肥健純先生，大西公平 先生, 特別会員 1 名, 吉峰俊樹先生の推萀があり, 賛 成多数にて承認されました。

\section{CARS2019/IPCAI2019 お知らせ}

第33回国際コンピュータ支援放射線医学・外科学会 議 (Computer Assisted Radiology and Surgery $33^{\text {rd }}$ International Congress and Exhibition) CARS 2019 が, フランス のレンヌで開催されます。

本大会は以下の大会の共催となります。

$\cdot 33^{\text {rd }}$ International Congress and Exhibition on Computer Assisted Radiology (CAR)

- $23^{\text {rd }}$ Annual Conference of the International Society for Computer Aided Surgery

- $21^{\text {st }}$ International Workshop on Computer-Aided Diagnosis and Artificial Intelligence

- $25^{\text {th }}$ Computed Maxillofacial Imaging Congress 


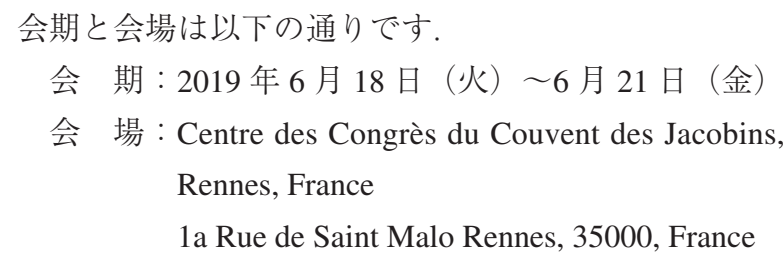

Paperまたは Abstract を投稿する形式となっていま す. CASの分野に関しては以下の Topicsが取り上げら れています。

—Artificial Intelligence Assisted Surgery

-Machine Learning in Surgery

-Augmented Reality, Virtual Reality for Surgery and Interventions

- Image Processing and Visualization

- Intraoperative Devices and Sensors

-Intraoperative Imaging

-Computer-assisted Planning

- Surgical Navigation

-Navigated Control

- Surgical Robotics and Instrumentation

-3D Modelling and Rapid Prototyping

- Methods of Validation and Verification

—Evaluation of CAS Systems

-Postoperative Result Assessment

- Surgical Knowledge and Decision Management

—Decision and Action Support in Surgical Management

- Situation Awareness in the OR

- Surgical Skill Assessment

- Surgical Workflow Analysis

- Surgical Simulation, Education and Training

—Ergonomics, User Interfaces, Haptics and Multimodal Devices in Surgical Applications

-Brain-Computer Interface, Neurostimulation

- Computer aided surgery in neuro, ENT, orthopaedic and spinal, cardiovascular, thoracic, gastroenterological, gynaecological, and urological surgery

- Image Guided Navigation Surgery

- Minimally Invasive Robotic Surgery

-Image Guided Therapy
その他の詳細，および登録申込みに関しては，ホー ムページ，または以下の事務局に㧍問い合わせくださ い.

E-mail : office@cars-int.org

\section{IPCAI 2019}

医療に対するコンピュータ応用に関する話題が提供 される $10^{\text {th }}$ International Conference on Information Processing in Computer-Assisted Interventions (IPCAI2019) もCARS2019と 2 日併催で開催されます。

会 期：2019年 6 月 18 日（火） 6月 19 日（水）

会 場：Centre des Congrès du Couvent des Jacobins, Rennes, France

1a Rue de Saint Malo Rennes, 35000, France

U R L : https://www.ipcai2019.org/

その他の詳細，および登録申込みに関しては，ホー ムページを参照してください.

Topics :

- Surgical data science

- Interventional imaging

- Systems and software

-Evaluation and validation

- Tracking and navigation

- Interventional robotics

- Surgical planning and simulation

- Advanced intra-operative visualization and user interfaces

- Augmented reality for medical application

— Surgical skill analysis and workflow

\section{MICCAI 2019 お知らせ}

The $22^{\text {nd }}$ International Conference on Medical Image Computing and Computer-Assisted Intervention (MICCAI 2019）が, 下記の要項で開催されます.

$$
\begin{aligned}
& \text { 会 期：2019年 } 10 \text { 月 } 13 \text { 日（日）～10月 } 17 \text { 日（木） } \\
& \text { 会 場：InterContinental Shenzhen, No. } 9009 \text { Shennan } \\
& \text { Road, Overseas Chinese Town：Shenzhen, } \\
& \text { 518053, China }
\end{aligned}
$$


U R L : http://www.miccai2019.org/

その他の詳細，および登録申达みに関しては，ホー ムページを参照してください.

Topics :

- Machine Learning and Artificial Intelligence

-Image Segmentation, Registration and Fusion

- Image Reconstruction and Image Quality

— Neuro Imaging

- Computational Anatomy and Physiology

-Microscopy and Histology Image Analysis

-Computer Aided Diagnosis

- Population Imaging and Imaging Genetics

-Applications of Big Data in Imaging

-Integration of Imaging with Non-Imaging Biomarkers

-Visualisation in Biomedical Imaging

- Surgical Data Science

- Interventional Imaging Systems

-Image-Guided Interventions and Surgery

- Surgical and Interventional Simulation Systems

- Interventional Tracking and Navigation

- Medical Robotics and Haptics

—Surgical Data Science

- Surgical Skill and Work Flow Analysis

- Surgical Planning and Simulation

- Surgical Visualization and Mixed, Augmented and Virtual Reality

-Interventional Software and User Interfaces

-Optical and Photo-acoustic Imaging

\section{関連学会のお知らせ}

\section{i ）第 58 回日本生体医工学会大会}

第 58 回日本生体医工学会大会が医看工融合が医療 を変える!」をテーマに沖縄コンベンションセンター にて開催されます。医学と工学が連携した生体医工学 に関連する研究開発成果が発表されます。また，第 7 回看護理工学会学術集会と合同開催となります.

会 期：2019年 6 月 6 日（木） 6月 8 日（土）

会 場：沖縄コンベンションセンター ７ 901-2224 沖縄県宜野湾市真志喜 4-3-1
U R L : http://jsmbe2019.com/

運営事務局：

E-mail : info@jsmbe2019.com

\section{ii ）第 7 回看護理工学会学術集会}

第 7 回看護理工学会学術集会が「医・看・工融合が 医療を変える」をテーマに沖縄コンベンションセン ターにて開催されます。看護学, 医学, 工学, 理学の 広範な領域の研究者が集まり看護と理工学の連携研究 に関連する研究開発成果が発表されます。また，第 58 回日本生体医工学会大会と合同開催となります。

$$
\begin{gathered}
\text { 会 期 }: 2019 \text { 年 } 6 \text { 月 } 6 \text { 日 }(\text { 木 }) \sim 6 \text { 月 } 8 \text { 日（土） } \\
\text { 会 場：沖縄コンベンションセンター } \\
\quad \text { † 901-2224 沖縄県宜野湾市真志喜 4-3-1 }
\end{gathered}
$$

U R L : https://nse2019.8href.com/index.html

\section{学術集会事務局}

\section{看護理工学会第 7 回学術集会 事務局}

干 265-8501 千葉県千葉市若葉区御成台 4-1

東京情報大学看護学部遠隔看護実践研究センター

TEL : 043-235-7379 FAX : 043-235-7413

E-mail : trec.tuis@gmail.com

事務関連問い合わせ

株式会社沖縄コングレ：コンベンション事業部

干 900-0015 沖縄県那覇市久茂地 3-1-1 日本生命 那覇ビル

TEL : 098-869-4220 FAX : 098-869-4252

E-mail : convention-staff@okicongre.jp

\section{iii）生体医工学シンポジウム 2019}

理工系・医学系研究者間のコミュニケーションの場 の提供および研究活動促進, そして迅速な研究成果報 告の場として, 生体医工学シンポジウム 2019 が下記の 要項で開催されます.

$$
\begin{aligned}
& \text { 会 期：2019年 } 9 \text { 月 } 6 \text { 日（金）～9 月 } 7 \text { 日（土） } \\
& \text { 会 場: 徳島大学（常三島キャンパス） } \\
& \text { 干 770-8506 徳島県徳島市南常三島町 2丁 } \\
& \text { 目 } 1 \text { 番地 }
\end{aligned}
$$

U R L : https://femto.me.tokushima-u.ac.jp/jbm es2019/index.html 
E-mail : jbmes2019@ml.tokushima-u.ac.jp

$\sim \sim \sim \sim \sim \sim \sim \sim \sim \sim \sim \sim \sim \sim \sim \sim \sim \sim \sim \sim$

iv）第 13 回日本 CAOS 研究会

日本での整形外科分野へのコンピュータ支援手術の 普及を目的とした第 13 回日本 CAOS 研究会が「未来 を拓く最先端技術」をテーマに下記の要項で開催され ます。

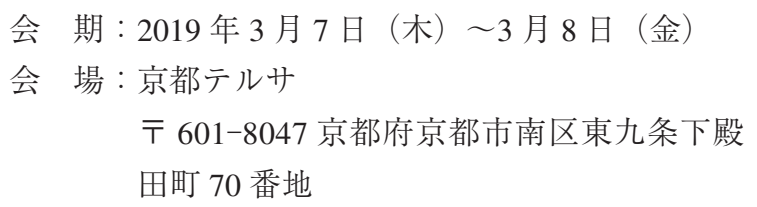

U R L : http://www.cs-oto.com/13caos/index.html

運営事務局：オフィス・テイクワン

干 451-0075 愛知県名古屋市西区康生通 2-26

TEL : 052-508-8510 FAX : 052-508-8540

E-mail : 13caos@cs-oto.com

$\sim \sim \sim \sim \sim \sim \sim \sim \sim \sim \sim \sim \sim \sim \sim \sim \sim \sim \sim \sim \sim \sim \sim \sim$

v) CAOS International 2019

整形外科分野を中心としたコンピュータ外科に関す る国際会議 The 19th Annual Meeting of the International Society for Computer Assisted Orthopaedic Surgery がアメ リカのニューヨークにて下記の要項で開催されます.

会 期：2019年 6 月 19 日（水） 6 月 22 日（土）

会 場：The New York Hilton Midtown

1335 Avenue of the Americas New York, NY 10019

U R L : https://caos2019.com/

Topics :

-Imaging (morphol. / functional, upright, dynamic, $\cdots$ )CT, MRT, US, Elastography, PET, OCT, $\cdots$ )

-Image Processing/Signal Processing

-Registration \& Data Fusion

-Knowledge Based Systems and Databases (Statistical Models, Biomechanical Models, Process/Workflow Models, $\cdots$ )

- Simulators \& Planning Software

-Robotics

- Navigation

- PSI/individual templates

-Patient specific implants

- Smart instruments and implants
—New Sensors \& Actuators (mechatronic components)

- Control/real time control

-Additive manufacturing ("3D-Printing")

- Shock Waves and Therapeutic Ultrasound/HIFU

- Computer Assisted Laser surgery

- Internet of Things (IOT)-Interoperability

-Medical Apps

- Surgical Process Management/Monitoring Software

- Mechanical/mechatronic assist devices

- Smart Patient Positionning

-Integrated Surgical Workplace/Operating Room Design Concepts

\section{vi ) Photonics West 2019}

画像工学, 光工学関連の最新の研究成果が発表され る SPIE (The International Society for Optical Engineering）主催による Photonic West 2019 がアメリカのサン フランシスコで開催されます。BiOS (Biomedical Optics), Translational Research, OPTO (Optoelectronic Materials, Devices, and Applications), LASE (Lasers and Applications), 3D Printing, Brainの学会が下記の要 領で同時開催されます.

会 期： 2019 年 2 月 2 日（土） 2 月 7 日（木）

会 場：The Moscone Center, San Francisco, California, USA

U R L : https://spie.org/conferences-and-exhibitions/ photonics-west

Topics (BiOS)

-Photonic Therapeutics and Diagnostics

-Neurophotonics, Neurosurgery, and Optogenetics

-Clinical Technologies and Systems

- Tissue Optics, Laser-Tissue Interaction, and Tissue Engineering

-Biomedical Spectroscopy, Microscopy, and Imaging

-Nano/Biophotonics

-BRAIN

- Translational Research

-3D Printing

vii) Medical Imaging 2019

医用画像に関する基礎研究から臨床応用までの最新 の研究成果が発表される Medical Imaging がアメリカ のサンディエゴで下記の要領で開催されます. 
会 期： 2019 年 2 月 16 日（土）～2 月 21 日（木）

会 場：Town and Country Resort \& Convention Center, San Diego, California, USA

U R L : https://spie.org/conferences-and-exhibitions/ medical-imaging/

Topics

-Physics of Medical Imaging

-Image Processing

-Computer-Aided Diagnosis

-Image-guided Procedures, Robotic Interventions, and Modeling

-Biomedical Applications in Molecular, Structural, and Functional Imaging

-Image Perception, Observer Performance, Technology Assessment

- Imaging Informatics for Healthcare, Research, and Applications

-Ultrasonic Imaging, Tomography, and Therapy

-Digital Pathology

$\sim \sim \sim \sim \sim \sim \sim \sim \sim \sim \sim \sim \sim \sim \sim \sim \sim \sim \sim \sim \sim \sim \sim \sim$

\section{viii) HSMR 2019}

The Hamlyn Centre for Robotics Surgery が主催する医 療用ロボット技術に関するシンポジウム Hamlyn Symposium on Medical Robotics（HSMR 2019）がイギリス のロンドンにて開催されます。会期と会場を以下に示 します.

会 期：2019年 6 月 23 日（日） 6 月 26 日（水）

会 場 : The Royal Geographical Society

1 Kensington Gore

London SW7 2AR, England

U R L : https://www.ukras.org/hamlyn/

Paper 期限：2019 年 3 月 31 日（日）

最終原稿期限：2019 年 5 月 13 日（月）

Topics :

- New instruments and novel mechatronic designs

-Intra-operative imaging and sensing

-Biophotonics for robotic surgery

-Bioinspired robotics

-Soft robotics

-Continuum robots (e.g. catheter, concentric tube robots)

- MR compatible robots
- Smart surgical instruments

- Microbot design and applications

- Learning and $\mathrm{co}^{-}$operative control

- Robotic surgical workflows and analytics

- Surgical vision and augmented reality

- Surgical simulation, training and skills assessment

-Wearable and assistive/rehabilitation robots

- Human robot interaction and ergonomics

- Clinical highlights and first in human studies

-Emerging, multi-specialty applications of robotic technology

-Economic and general consideration of robotic surgery

$\sim \sim \sim \sim \sim \sim \sim \sim \sim \sim \sim \sim \sim \sim \sim \sim \sim \sim \sim \sim \sim \sim \sim \sim$

ix) ISBI 2019

医用および生体に関する画像工学の国際会議 2019

IEEE International Symposium on Biomedical Imaging が イタリアのヴェニスにて下記の要項で開催されます。

会 期：2019年 4 月 8 日（月）～4月 11 日（木）

会 場 : Hilton Molino Stucky, Venice Italy

U R L : https://biomedicalimaging.org/2019/

\section{x ) ЕМВC 2019}

Medical Physics と Biomedical Engineering に関連する 学会として 41st Annual International Conference of the IEEE Engineering in Medicine and Biology Society (EMBC2019) が下記の要項にてドイツのベルリンで開 催されます。“Biomedical engineering ranging from wellness to intensive care”が今大会のテーマです.

$$
\begin{aligned}
\text { 会 期： } 2019 \text { 年 } 7 \text { 月 } 23 \text { 日（火）～7月 } 27 \text { 日（土） } \\
\text { 会 場：CityCube Berlin } \\
\text { Messedamm } 2614055 \text { Berlin/Germany }
\end{aligned}
$$

U R L : http://embc.embs.org/2019/

$$
\begin{array}{ll}
4 \text { pages paper } & \\
\text { 投稿期限 } & : 2019 \text { 年 } 2 \text { 月 } 5 \text { 日（火） } \\
\text { 採否通知 } & : 2019 \text { 年 } 4 \text { 月 } 5 \text { 日（金） } \\
\text { 最終原稿期限 : } 2019 \text { 年 } 4 \text { 月 } 17 \text { 日（水） }
\end{array}
$$

1 page abstract

投稿期限 : 2019 年 4 月 12 日（金）

採否通知：2019年 4 月 23 日（火）

最終原稿期限：2019 年 4 月 30 日（火） 
Topics :

-Biomedical Signal Processing

— Biomedical Imaging and Image Processing

-Micro/Nano-bioengineering and Cellular/Tissue Engineering \& Biomaterials

- Computational Systems, Modeling and Simulation in Medicine, Multiscale Modeling, Synthetic Biology

- Cardiovascular and Respiratory Systems Engineering

- Neural and Rehabilitation Engineering

-Biomedical Sensors and Wearable Systems

-Bio-Robotics and Biomechanics

- Therapeutic and Diagnostic Systems and Technologies

-Biomedical and Health Informatics

-Biomedical Engineering Education and Society

- Translational Engineering for Healthcare Innovation and Commercialization

- Pharmaceutical Engineering and Drug Delivery Systems

-Smart Implants

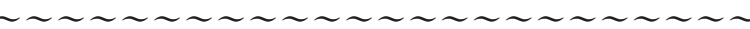

xi）第 28 回ライフサポート学会フロンティア講演会

生活・生命支援関連の若手研究者を中心とした研究 発表が行われる第 28 回ライフサポート学会フロン ティア講演会が下記の要項で開催されます。

$$
\begin{aligned}
& \text { 会 期：2019 年 } 3 \text { 月 } 15 \text { 日（金） 3 月 } 16 \text { 日（土） } \\
& \text { 会 場：埼玉医科大学 日高キャンパス } \\
& \text { 干 350-1241 埼玉県日高市山根 1397-1 }
\end{aligned}
$$

U R L : http://www.jslst.net/frontier_hp/28/

演題申込み締切 2019 年 1 月 18 日（金）

\section{xii) LIFE 2019}

人の生命・生活を維持・向上させる生命関連分野, リハビリテーション・生活支援分野, 生体計測・制御 分野等に扔ける技術研究開発, 利用技術に関する研究 成果が発表される生活生命支援医療福祉工学系学会連 合大会（LIFE2019）が下記の要項で開催されます。本 大会は以下の学会の主催となります。

日本機械学会福祉工学シンポジウム 2019（幹事学 会）

第 35 回ライフサポート学会

第 19 回日本生活支援工学会
会 期：2019 年 9 月 12 日（木） 9 月 14 日（土）

会 場：慶應義塾大学日吉キャンパス

干 223-8521 神奈川県横浜市港北区日吉 4-1-1

U R L ： https://www.jsme.or.jp/conference/life2019/

E-mail :life2019@jsme.or.jp

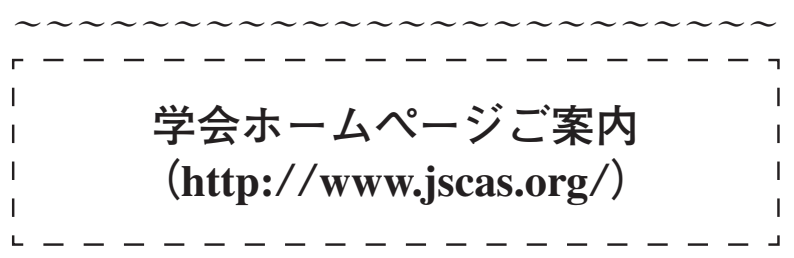

日本コンピュータ外科学会では, ホームページ （http://www.jscas.org/）にて以下のような情報の提供 を行っております。

一日本コンピュー夕外科学会の趣旨

一入会のご案内

一日本コンピュータ外科学会大会のご案内

一日本コンピュー夕外科学会論文誌投稿のご案内

一既刊の日本コンピュータ外科学会論文誌の電子 アーカイブ

一過去開催された日本コンピュータ外科学会大会 データベース

一CASニュースレター オンライン

一その他の㧍知らせ等ご案内

今後，ますます内容の充実を図っていきたいと考え ておりますので, 皆様のご希望, ご意見など学会事務 局までお寄せいただければ幸いです。

\section{あとがき}

\section{投稿，お便りの募集}

JSCAS Newsletterでは，皆様からの投稿やお知らせ を募集しています。研究紹介や関連学会案内, 参加報 告などを奮ってご応募ください.

また，皆様からの企画などもありましたらお知らせ いただけると幸いです。 


\section{JSCAS Newsletter No. 73}

編集: 日本コンピュー夕外科学会広報委員会 芝浦工業大学 花房昭彦

日本医療機器テクノロジー協会 三澤 裕 東京女子医科大学 小林英津子

医療機器センター 鈴木孝司

慶應義塾大学 中澤和夫

東京女子医科大学 岡本 淳

大阪大学 小林 洋

岡山理科大学 松宮 潔

産業技術総合研究所 熟尾利克

東京電機大学 桑名健太

学会事務局：日本コンピュー夕外科学会

₹ 111-0054

東京都台東区鳥越二丁目 13 番 8 号

（株）ライフメディコム内

TEL : 03-5809-1933

FAX : 03-5820-1898

E-mail : office@jscas.org

URL : http://www.jscas.org/ 